\title{
EVALUASI PENGENDALIAN INTERNAL SISTEM INFORMASI AKUNTANSI PENJUALAN DAN PENERIMAAN KAS PADA PT. HASJRAT ABADI CABANG MALALAYANG MANADO
}

\author{
Novita Kalumata ${ }^{1}$, Grace B. Nangoi ${ }^{2}$, Robert Lambey ${ }^{3}$ \\ ${ }^{1,2,3}$ Fakultas Ekonomi dan Bisnis, Jurusan Akuntansi, Universitas Sam Ratulangi, Jl. Kampus Bahu, Manado, \\ 95115, Indonesia \\ E-mail : novitakalumata95@gmail.com
}

\begin{abstract}
Internal Control Accounting Information System serves to maintain the company's wealth to check the accuracy and reliability of accounting data financial statements, encourage efficiency, and encourage compliance with management policies. Improper sales and cash receipts management will be detrimental to the company. Therefore, companies need the internal control of accounting information system sales and cash receipts in order to reduce the possibility of fraud, waste, ineffectiveness and inefficiency that can harm the company. The purpose of this study is to evaluate the internal control of accounting information systems sales and cash receipts at PT. Hasjrat Abadi Malalayang Manado Branch. This research uses a descriptive method. The results Show that the internal control of accounting information systems sales and cash receipts at PT. Hasjrat Abadi Malalayang Branch Manado is appropriate, it is seen from the implementation of elements of internal control is adequate and adequate supported by policies and procedures of sales and cash receipt is good in accordance with the theory of COSO.

Keywords: Internal Control of Accounting Information System, Sales and Cash Receipts
\end{abstract}

\section{PENDAHULUAN}

Kemajuan dan perkembangan lingkungan dunia usaha pada saat ini telah berkembang sangat cepat dan tepat. Adanya perkembangan industri yang semakin kompetitif dari waktu kewaktu menyebabkan setiap perusahaan harus siap menghadapi persaingan yang semakin ketat. Persaingan usaha merupakan faktor penting dalam meningkatkan kinerja perusahaan agar dapat meningkatkan kualitas yang dihasilkan yang didukung dengan adanya pengendalian internal. Adry \& Tirtajaya (2015) Pengendalian internal yang baik harus dimiliki setiap perusahaan tanpa terkecuali. Pengendalian internal dalam perusahaan adalah untuk menjaga dan memastikan setiap aktivitas dalam perusahaan sesuai dan sejalan dengan tujuan perusahaan. Agar tetap unggul ditengah-tengah ketatnya persaingan bisnis, maka performa yang baik ini dihasilkan dari adanya suatu pengendalian internal.

Menurut COSO yang dikutip oleh Hesty (2013:11) Pengendalian internal adalah suatu proses, melibatkan seluruh anggota organisasi, dan memiliki tujuan utama yaitu efektivitas, efesiensi operasional, kehandalan laporan keuangan, dan kepatuhan atas hukum dan peraturan yang berlaku. Artinya, dengan adanya pengendalian internal maka diharapkan perusahaan dapat bekerja secara efektif dan efisien, penyajian informasi dapat diyakini kebenarannya dan semua pihak akan mematuhi semua peraturan dan kebijakan yang ada dengan dipatuhinya peraturan dan kebijakan maka penyimpangan dapat dihindari. Pengendalian internal secara ketat maka diharapkan bahwa seluruh kegiatan operasional perusahaan dapat berjalan dengan baik. Bahkan tidak hanya dari segi operasional saja yang akan berjalan dengan tertib dan baik sesuai prosedur, akan tetapi dari segi finansial perusahaan juga dapat lebih termonitor dengan baik. Pada dasarnya, faktor efisien dan efektivitas perusahaan merupakan dua hal yang juga merupakan sasaran yang diterapkannya pengendalian internal, karena jika pengendalian internal tidak berjalan sebagaimana yang diharapkan, maka kemungkinan besar (hampir 
dapat dipastikan) akan timbul yang namanya (pemborosan sumber daya) yang pada akhirnya akan membebani tingkat profitabilitas (keuntungan) perusahaan.

Dalam meningkatkan profitabilitas (keuntungan) terdapat sistem yang digunakan dalam perusahaan mengenai sistem informasi akuntansi (SIA). Sistem informasi akuntansi (SIA) adalah sebuah subsistem dari sistem informasi manajemen yang menyediakan informasi akuntansi dan keuangan bersama informasi lainnya, yang diperoleh dalam proses transaksi akuntansi yang rutin. Sistem informasi akuntansi yang baik dapat membantu sebuah perusahaan untuk menyediakan kebutuhan perusahaan akan informasi-informasi akuntansi dan informasi-informasi lainnya yang berkaitan dengan proses bisnis yang ada dalam perusahaan tersebut. Dengan adanya sistem informasi akuntansi akan meningkatkan kinerja perusahaan terhadap berbagai sumber daya yang dimiliki perusahaan (Tresnawati 2017).

Perusahaan membutuhkan pengamanan yang baik atas aktiva yang dimilikinya agar tidak terjadi hal-hal yang merugikan perusahaan seperti penyelewengan, kerusakan dan kehilangan yang dilakukan oleh pihak yang tidak bertanggung jawab, sehingga suatu perusahaan memerlukan sistem dan prosedur yang dapat menjamin terlaksananya aktivitas perusahaan secara efektif dan efisien yang diaplikasikan ke dalam sistem informasi akuntansi. Usaha yang perlu dilakukan untuk membantu menjaga keamanan harta perusahaan adalah menyusun sistem informasi akuntansi dengan mempertimbangkan prinsip-prinsip pengawasan internal untuk menghindari kecurangan yang dapat terjadi yang dapat mempengaruhi kelangsungan perusahaan (Alifa, 2013). Dalam perusahaan terdapat sistem informasi akuntansi penjualan dan penerimaan kas. Sistem informasi akuntansi penjualan dan penerimaan kas merupakan salah satu subsistem informasi akuntansi yang menjelaskan bagaimana seharusnya prosedur dalam melakukan kegiatan penjualan dan penerimaan kas dari hasil penjualan sehingga tindakan kecurangan terhadap penjualan dan penerimaan kas dapat dihindari.

Tanpa adanya pengendalian internal sistem informasi akuntansi yang baik perusahaan bisa saja mengalami kerugian yang mengancam perusahaan tersebut karena kecurangan yang tidak terdeteksi maupun kerena pengelolaan sumber daya yang tidak maksimal. Oleh kerena itu, pada dasarnya perusahaan baik besar maupun kecil, perlu memperhatikan dan memahami cara pengendalian internal sistem informasi akuntansi (SIA) penjualan dan penerimaan kas. Pengendalian internal sistem informasi akuntansi juga sangat penting dilakukan oleh PT. Hasjrat Abadi agar menghasilkan tujuan perusahaan yang efektif dan efisien. Kegiatan operasional yang dilakukan oleh PT. Hasjrat Abadi Cabang Malalayang Manado adalah melaksanakan penjualan kendaraan motor baik penjualan tunai maupun penjualan secara kredit. Banyaknya aktivitas penjualan pada perusahaan menjelaskan sangat penting pengendalian internal sistem informasi akuntansi guna memenuhi kebutuhan keamanan harta kekayaan perusahaan dari tindakan penyelewengan yang dilakukan oleh karyawan perusahaan.

\section{TINJAUAN PUSTAKA}

\subsection{Pengendalian Internal}

Pengendalian internal ialah suatu proses yang dipengaruhi oleh dewan komisaris, manajemen, dan personil satuan usaha lainnya, yang dirancang untuk mendapatkan keyakinan memadai tentang pencapaian tujuan dalam hal-hal berikut: keandalan pelaporan keuangan, kesesuaian dengan undang-undang, dan peraturan yang berlaku, efektivitas dan efisiensi operasi Iskandar (2015).

\subsubsection{Unsur- Unsur Pengendalian Internal}

Menurut COSO dalam Susanto (2013: 96) pengendalian internal memiliki lima kompenen antara lain sebagai berikut : 
1. Lingkungan Pengendalian

2. Penilaian Resiko

3. Pengendalian Aktivitas

4. Informasi dan Komunikasi

5. Monitoring (Pemantauan)

\subsubsection{Prinsip-prinsip Pengendalian Internal yang Efektif}

Hery (2014: 162-169) Prinsip-prinsip pengendalian internal yang efektif antara lain adalah sebagai berikut :

1. Penetapan tanggung jawab

2. Pemisahan tugas

3. Dokumentasi

4. Pengendalian fisik mekanik dan elektronik

5. Pengecekan independen atau verifikasi internal.

\subsubsection{Prosedur Pengendalian}

Lumempow (2015) Prosedur pengendalian merupakan kebijakan dan aturan mengenai kelakuan karyawan yang dibuat untuk menjamin bahwa tujuan pengendalian manajemen dapat tercapai. Secara umum prosedur pengendalian yang baik terdiri dari :

1. Penggunaan wewenang secara tepat untuk melakukan suatu kegiatan atau transaksi.

2. Pembagian tugas.

3. Pembuatan dan penggunaan dokumen dan catatan yang memadai.

4. Keamanan yang memadai terhadap aset dan catatan.

5. Pengecekan independen terhadap kinerja.

\subsubsection{Tujuan Pengendalian Internal}

Menurut COSO dalam Susanto (2013: 95) pengendalian internal dapat didefinisikan sebagai suatu proses yang dipengaruhi oleh dewan direksi manajemen dan karyawan yang dirancang untuk memberikan jaminan yang menyakinkan bahwa tujuan organisasi akan dapat dicapai melalui hal-hal sebagai berikut :

1. Efisiensi dan Efektivitas operasi.

2. Penyajian laporan keuangan yang dapat dipercaya.

3. Ketaatan terhadap undang-undang dan aturan yang berlaku

\subsubsection{Pengendalian internal atas Penjualan Tunai dan Kredit}

Dalam hal penjualan tunai hal yang perlu diperhatikan untuk mengatasi adanya kecurangan yang rentan dilakukan oleh pegawai sebaiknya dilakukan pemisahan tugas antara orang yang mengelola penjualan dengan yang mengelola kas sementara (kassa) seharusnya tidak dikelola oleh satu orang saja untuk menghindari adanya penggelapan danah yang dilakukan oleh kassa secara mudah. Selain itu pita cash register juga sangat berperan besar dalam hal penanggulangan penggelapan danah yang dilakukan oleh kassa dengan mengeluarkan cash register sebagai bukti pembayaran yang dilakukukan oleh pelanggan, karena pelanggan dapat mengecek kesesuaian jumlah yang harus dibayar dengan jumlah pembayaran yang diserahkan kepada kassa.

Pengendalian internal dalam penjualan kredit dapat dilakukan dengan pencatatan penjualan yang didukung oleh dokumen pengiriman yang sah dan pesanan pelanggan yang telah disetujui untuk menghindari adanya penjualan fiktif. Selain itu adanya otorisasi kredit atas transaksi penjualan yang sah dalam untuk setiap prosedur persetujuan kredit sebelum pengiriman, otorisasi pengiriman barang, dan otorisasi penentuan harga dan syarat-syarat penjualan, pengangkutan dan potongan secara jelas.

\subsection{Sistem Informasi Akuntansi}

Sujarweni (2015:1) Menyatakan bahwa sistem adalah kumpulan elemen yang saling berkaitan dan bekerjasama dalam melakukan kegiatan untuk mencapai suatu tujuan. Pengertian sistem dilihat dari masukan dan keluarannya. Sistem adalah suatu rangkaian yang 
berfungsi menerima input (masukan), mengolah input, dan menghasilkan output (keluaran). Sistem yang baik akan bertahan dalam lingkungannya.

Informasi adalah data yang telah dikelola dan diproses untuk memberikan arti dan memperbaiki proses pengambilan keputusan. Sebagaimana perannya, pengguna membuat keputusan yang lebih baik sebagai kuantitas dan kualitas dari peningkatan informasi (Romney dan Steinbart 2015). Informasi adalah hasil dari proses atau hasil pengolahan data, meliputi hasil gabungan, analisis, penyimpulan, dan pengolahan sistem informasi komputerisasi. Akuntansi adalah proses dari transaksi yang dibuktikan dengan faktur, lalu dari transaksi dibuat jurnal, buku besar, neraca lajur, kemudian menghasilkan informasi dalam bentuk laporan keuangan yang digunakan untuk pihak-pihak tertentu.

\subsection{Sistem Informasi Akuntansi Penjualan}

Daud dan Mindana (2014) Sistem Informasi Akuntansi Penjualan adalah suatu sistem informasi yang mengorganisasikan serangkaian prosedur dan metode yang dirancang untuk menghasilkan, menganalisa, menyebarkan dan memperoleh informasi guna mendukung pengambilan keputusan mengenai penjualan.

\subsection{Sistem Informasi Akuntansi Penjualan Kredit}

a. Menurut Krismiaji (2010:307) bagian yang terkait dalam prosedur penjualan kredit adalah sebagai berikut :

1. Bagian Penjualan

2. Bagian Kredit

3. Bagian Gudang

4. Bagian pengiriman

5. Bagian Penagihan.

6. Bagian Piutang

b. Dokumen yang digunakan dalam penjualan kredit (Mulyadi, 2014:214) adalah sebagai berikut :

1. Surat Order Pengiriman

2. Faktur Penjualan dan Tembusan

3. Rekapitulasi Harga Pokok Penjualan

4. Bukti Memorial

c. Catatan akuntansi yang digunakan dalam sistem penjualan kredit menurut Mulyadi (2014: 218) adalah :

1. Jurnal Penjualan

2. Kartu Piutang

3. Kartu Persediaan

4. Kartu Gudang

5. Jurnal Umum

d. Jaringan prosedur yang membentuk sistem penjualan kredit menurut Mulyadi (2014: 219) adalah :

1. Prosedur order penjualan

2. Prosedur persetujuan kredit

3. Prosedur pengiriman

4. Prosedur penagihan

5. Prosedur pencatatan piutang

6. Prosedur distribusi penjualan

7. Prosedur pencatatan harga pokok penjualan

\subsection{Sistem Penerimaan Kas dari Piutang}

Sistem penerimaan kas dari piutang dalam perusahaan berasal dari penjualan tunai dan penerimaan kas dari pelunasan piutang, sumber penerimaan kas dari dari suatu perusahaan berasal dari pelunasan piutang oleh para debitur, dimana produk perusahaan 
dengan cara mengirim barang sesuai dengan order yang diterima dari pembeli dan dalam jangka waktu tertentu perusahaan mempunyai tagihan kepada pembeli tersebut.

\subsection{Sistem Informasi Akuntansi Penjualan Tunai}

Dokumen yang digunakan dalam penjualan tunai menurut Mulyadi (2014:463) adalah sebagai berikut :

1. Faktur penjualan tunai (FPT)

2. Pita Register

\subsection{Sistem Akuntansi Penerimaan Kas}

Penerimaan kas adalah kas yang diterima perusahaan baik yang berupa uang tunai maupun surat berharga yang mempunyai sifat dapat segera digunakan, yang berasal dari transaksi perusahaan maupun penjualan tunai, pelunasan piutang atau transaksi lainnya yang dapat menambah kas perusahaan. Esteria (2016).

\subsection{Sistem Penerimaan Kas dari Penjualan Tunai}

Sistem penerimaan kas dari penjualan tunai mengharuskan penerimaan kas dalam bentuk tunai harus segera disetor ke-bank dalam jumlah penuh dengan cara melibatkan pihak lain selain kasir untuk melakukan internal check. Penerimaan kas dari penjualan tunai juga dilakukan melalui transaksi kartu kredit, yang melibatkan Bank penerbit kartu kredit dalam pencatatan transaksi penerimaan kas. Sumurung 2015).

\subsection{Penelitian Terdahulu}

Any Krisnawaty (2013) dalam penelitian Analisis sistem Informasi Akuntansi penjualan dan penerimaan kas (Studi Pada PenjualanSpeedy PT. Telekomunikasi Indonesia,Tbk Kandatel Malang. Hasil Penelitian menunjukkan bahwa sistem informasi akuntansi penjualan dan penerimaan kas telah mencerminkan adanya sistem pengendalian intern yang baik, meskipun masih terdapat beberapa kelemahan, yaitu dokumen yang digunakan masih ada yang menggunakan sistem manual.Saran yang dapat diberikan peneliti adalah dokumen yang digunakan sebaiknya menggunakan sistem online agar lebih praktis dan efisien.

\section{METODE PENELITIAN}

3.1. Jenis Penelitian

Jenis Penelitian yang dilakukan adalah jenis penelitian deskriptif. Penelitian Deskriptif meliputi pengumpulan data untuk diuji hipotesis atau menjawab pertanyaan mengenai status terakhir dari subjek penelitian.

\subsection{Tempat Dan Waktu Penelitian}

Penelitian ini dilakukan di PT. Hasjrat Abadi Cabang Malalayang Kota Manado, Sulawesi Utara. Waktu penelitian yaitu dari bulan April sampai November 2017.

\subsection{Sumber Data}

Menurut Sugiyono yang dikuti oleh Hamel (2013)

a. Data Primer adalah sumber data yang langsung memberikan kepada pengumpul data. Data primer diperoleh dengan cara observasi dan wawancara dengan pimpinan perusahaan.

b. Data Sekunder, merupakan data yang tidak langsung diberikan pada pengumpul data, misalnya dokumen. Data sekunder yang diperoleh berupa catatan-catatan, laporan keuangan dan berbagai publikasi yang relevan terkait dengan masalah yang diangkat.

\subsection{Prosedur Panelitian}

1. Mengidentifikasi permasalahan untuk dipecahkan melalui metode deskriptif.

2. Mengumpulkan data dan informasi yang jelas mengenai Pengendalian internal sistem informasi akuntansi penjualan dan penerimaan kas pada PT. Hasjrat Abadi Cabang Malalayang.

3. Merumuskan permasalahan yang jelas dan menentukan tujuan dan manfaat penelitian. 
4. Melakukan analisis data yang diperoleh dengan menggunakan analisis deskriptif.

5. Mengevaluasi data yang diperoleh mengenai pengendalian internal sistem informasi akuntansi penjualan dan penerimaan kas.

6. Mengajukan kesimpulan yang logis berdasarkan hasil penelitian tersebut dan memberikan saran pada PT. Hasjrat Abadi Cabang Malalayang Manado.

\subsection{Metode Pengumpulan Data}

1. Wawancara

2. Observasi

3. Dokumentasi

\subsection{Metode Analisis}

Metode yang digunakan untuk menganalisis data adalah metode deskripstif yaitu metode yang digunakan untuk menggambarkan atau menganalisis suatu hasil penelitian tetapi tidak digunakan untuk membuat kesimpulan yang lebih luas (Hesty, 2013:33).

\section{HASIL ANALISIS DAN PEMBAHASAN}

4.1. Hasil analisis

4.1.1 Pengendalian Internal Pada PT. Hasjrat Abadi Cabang Malalayang Manado

Pengendalian Internal yang diterapkan oleh PT. Hasjrat Abadi Cabang

Malalayang Manado mencakup berikut ini :

1. Lingkungan Pengendalian

Dalam lingkungan pengendalian integritas perusahaan menciptakan lingkungan kerja yang ramah dan kondusif, komitmen terhadap kompetisi dengan adanya Pembagian tugas yang jelas membuat pegawai memiliki tanggung jawab terhadap kewajibanya. Dengan adanyan pembagian tugas maka dapat menunjang keefektifan pengawasan melekat pada internal perusahaan, Filosofi manajemen Tujuan dasar setiap perusahan ingin medapatkan keuntungan yang sebesar-besarnya lewat penjualan kredit namun tidak sembarangan dalam memberikan kredit oleh karena itu ada tahapan-tahapan analisa yang dilakukan untuk memilih konsumen yang sehat demi kelangsungan perusahaan, dalam struktur organisasi Sudah baik, karena adanya hubungan secara langsung atasan dan bawahan. menyebabkan setiap bawahan hanya mengenal satu atasan sebagai pemberi wewenang, dalam kebijakan dan praktek sumber daya manusia sangat baik yang diterapkan PT. Hasjrat Abadi cabang malalayang manado agar setiap pegawai memiliki keahlian dan kompetensi dibidang kerjanya sehingga juga berpengaruh dalam jalannya kinerja perusahaan.

2. Penilaian Resiko

Untuk mengantisipasi kecurangan pada PT Hasjrat Abadi Cabang Malalayang dalam PT. Hasjrat Abadi manajemen menilai potensi risiko dan juga pimpinan sudah berupaya untuk menghilangkan manipulasi yang biasanya dilakukan terhadap ukuran kinerja seperti dorongan dan godaan kepada karyawan untuk bersikap tidak jujur dalam menjalankan tugasnnya.

3. Aktivitas Pengendalian

Untuk Mengurangi Terjadinya Kecurangan, Manajemen PT.Hasjrat Abadi telah merancang Kebijakan dan Prosedur yang harus ditaati setiap entitas.

4. Informasi dan Komunikasi

Informasi dan komunikasi, perusahaan telah menggunakan (DMS) Dealer management System yang mudah dan cepat dalam memperoleh data mengenai aktivitas penjualan dan penerimaan kas, sehingga informasi yang dibutuhkan manajemen dapat terpenuhi dengan cepat. Komunikasi Dengan adanya briefing lansung antara pegawai dengan atasan dapat menjadi ukuran perkembangan perusahaan serta pencarian solusi untuk tiap kendala yang dihadapi pegawai dalam menjalankan tugas. 
5. Monitoring/ Pemantauan

Aktivitas Pemantauan yang diterapkan oleh perusahaan membantu kepala cabang dimana Monitoring di bagian operasionalnya dilakukan secara langsung oleh pimpinan kantor PT. Hasjrat Abadi cabang malalayang manado lewat CCTV yang di pasang pada beberapa tempat dalam kantor dan luar kantor.

\subsubsection{Sistem Informasi Akuntansi Penjualan Tunai Pada PT. Hasjrat Abadi Cabang Malalayang Manado}

1. Penjualan Tunai

a. Prosedur Penjualan Tunai Pada PT. Hasjrat Abadi (Yamaha) Cabang Manado :

1. Konsumen langsung datang ke dealer.

2. Menyiapkan KTP yang masih berlaku.

3. Sales mengecek kendaraan yang dibutuhkan konsumen

4. Setelah konsumen memilih barang yang diinginkan, selanjutnya konsumen melakukan pembayaran di bagian kasir.

5. Bagian akuntansi melakukan penginputan kendaraan bermotor lewat sistem DMS (Dealer Management system) untuk mengeluarkan SO (Sales Order), DO (Delivery Order), dan Faktur penjualan sistem dari pihak perusahaan Hasjrat Abadi.

b. Bagian -bagian yang terkait dalam penjualan tunai

1. Bagian Sales

2. Bagian Kasir

3. Bagian PDI (Pre Delivery Inspection : pemeriksaan sebelum penyerahan kendaraan).

4. Bagian Akuntansi

4.1.3. Sistem Informasi Akuntansi Penjualan Kredit Pada PT. Hasjrat Abadi Cabang Malalayang Manado

Prosedur Penjualan Kredit Pada PT. Hasjrat Abadi (Yamaha) Cabang Manado

1. Konsumen harus melengkapi berkas.

2. Setelah itu bagian sales menghubungi survevor yang akan bersedia memeriksa alamat rumah konsumen.

3. Kemudian bagian leasing akan melakukan analysis kredit sesuai dengan kebutuhan motor dari konsumen dan konsumen akan menunggu persetujuan dari pihak leasing (kredit) yang menjamin kendaraan tersebut dalam bentuk surat PO. Batas lambat 2 hari setelah survey rumah konsumen.

4. Setelah itu konsumen melakukan pembayaran uang muka di dealer dan langsung penginputan SO (Sales Order), DO (Delivery Order), dan Faktur Penjualan sistem dari pihak perusahaan Hasjrat Abadi.

\subsubsection{Sistem Informasi Akuntansi Penerimaan Kas PT. Hasjrat Abadi Cabang Manado}

Penerimaan kas dari PT. Hasjrat Abadi Manado berasal dari penjualan tunai, penerimaan uang muka penjualan kredit, pelunasan piutang dari perusahaan leasing, penerimaan dari servis kendaraan. Penerimaan kas terbesar PT. Hasjrat Abadi Manado adalah penjualan kendaraan (Toyota dan Yamaha). Penjualan tunai kendaraan dilaksanakan dengan cara mewajibkan pembeli melakukan pembayaran harga kendaraan atau barang dagangan terlebih dahulu kepada bagian kasir sebelum kendaraan atau barang dagangan diserahkan oleh perusahaan kepada pembeli. 


\subsection{Pembahasan}

\subsubsection{Evaluasi Pengendalian Internal Pada PT Hasjrat Abadi Cabang Malalayang Manado}

\begin{tabular}{|c|c|}
\hline TEORI COSO & PT. Hasjrat Abadi \\
\hline $\begin{array}{l}\text { 1. Lingkungan Pengendalian } \\
\text { Lingkungan pengendalian adalah pembentukan } \\
\text { suasana organisasi serta memberi kesadaran } \\
\text { tentang perlunya pengendalian bagi suatu } \\
\text { organisasi ada beberapa faktor yang } \\
\text { mempengaruhi lingkungan pengendalian adalah } \\
\text { sebagai berikut: } \\
\text { a Integritas dan nilai etika } \\
\text { b. Komitmen terhadap kompetensi. } \\
\text { c Filosofi dan gaya manajemen } \\
\text { d Struktur organisasi } \\
\text { e Pemberian wewenang dan tanggung jawab } \\
\text { f Kebijakan mengenai sumber daya manusia dan } \\
\text { penerapannya }\end{array}$ & $\begin{array}{l}\text { 1. Lingkungan Pengendalian } \\
\text { a) Tingginya nilai integritas dan nilai etika pada } \\
\text { perusahaan } \\
\text { b)Berupaya untuk mengembangkan kemampuan } \\
\text { dari karyawan dengan cara pembinaan dan } \\
\text { mengembangkan karyawan } \\
\text { c) Terdapat Filosofi manajemen yang dapat } \\
\text { menyiapkan gerak langkah karyawan dalam } \\
\text { mencapai tujuan perusahan } \\
\text { d) Mempunyai bagan struktur organisasi dan } \\
\text { menerapkan struktur organisasi } \\
\text { e) Terdapat batasan dan tanggung jawab yang } \\
\text { cukup jelas } \\
\text { f) Kebijakan mengenai sumber daya manusia } \\
\text { yaitu prosedur perekrutan calon karyawan dengan } \\
\text { selektif }\end{array}$ \\
\hline $\begin{array}{l}\text { 2. Penilaian Resiko } \\
\text { Penilaian resiko melibatkan proses yang } \\
\text { dinamis dan interaktif untuk mengidentifikasi } \\
\text { dan menilai resiko terhadap pencapaian tujuan. } \\
\text { Resiko itu sendiri dipahami sebagai suatu } \\
\text { kemungkinan bahwa suatu peristiwa akan terjadi } \\
\text { dan mempengaruhi perncapaian tujuan entitas, } \\
\text { dan resiko terhadap pencapaian seluruh tujuan } \\
\text { dari entitas ini dianggap relative terhadap } \\
\text { toleransi resiko yang ditetapkan. Oleh karena itu, } \\
\text { penilaian resiko membentuk dasar untuk } \\
\text { menentukan bagaimana resiko harus dikelola oleh } \\
\text { organisasi }\end{array}$ & $\begin{array}{l}\text { a) Telah menerapkan Prosedur Penjualan } \\
\text { b) Memiliki prosedur dalam menyeleksi } \\
\text { karyawan baru }\end{array}$ \\
\hline $\begin{array}{l}\text { 3. Pengendalian Aktivitas } \\
\text { Pengendalian aktivitas adalah tindakan- } \\
\text { tindakan yang ditetapkan melalui kebijakan dan } \\
\text { prosedur yang membantu memastikan bahwa } \\
\text { arahan manajemen untuk mengurangi resiko } \\
\text { terhadap pencapaian. Pengendalian aktivitas } \\
\text { dilakukan pada semua tingkat entitas, pada } \\
\text { berbagai tahap dalam proses bisnis, dan atas } \\
\text { lingkungan teknologi. } \\
\text { a. kebijakan dan Prosedur } \\
\text { b. Pemisahan tugas } \\
\text { c. Dokumen yang digunakan }\end{array}$ & $\begin{array}{l}\text { a) Memiliki kebijakan dan prosedur dalam } \\
\text { melindungi harta perusahaan } \\
\text { b) Terdapat Pemisahan tugas yang memadai } \\
\text { c) Terdapat Dokumen-dokumen khusus }\end{array}$ \\
\hline $\begin{array}{l}\text { 4. Informasi dan Komunikasi } \\
\text { Menjelaskan bahwa informasi sangat penting } \\
\text { bagi setiap entitas untuk melaksanakan tanggung } \\
\text { jawab pengendalian internal guna mendukung } \\
\text { pencapaian tujuan-tujuannya. Informasi yang } \\
\text { diperlukan manajemen adalah informasi yang } \\
\text { relevan dan berkualitas baik yang berasal dari } \\
\text { sumber internal maupun eksternal dan informasi } \\
\text { yang digunakan untuk mendukung fungsi }\end{array}$ & $\begin{array}{l}\text { a) Menggunakan sistem yang terkomputerisasi } \\
\text { b) Briefing }\end{array}$ \\
\hline
\end{tabular}




\begin{tabular}{|c|c|}
\hline $\begin{array}{c}\text { TEORI COSO } \\
\end{array}$ & PT. Hasjrat Abadi \\
\hline $\begin{array}{l}\text { komponen-komponen lain pengendalian internal. } \\
\text { Informasi diperoleh ataupun dihasilkan melalui } \\
\text { proses komunikasi antar pihak internal maupun } \\
\text { eksternal yang dilakukan secara terus- menerus, } \\
\text { berulang, dan berbagi. Kebanyakan organisasi } \\
\text { membangun suatu sistem informasi untuk } \\
\text { memenuhi kebutuhan informasi yang andal, } \\
\text { relevan dan tepat waktu }\end{array}$ & \\
\hline $\begin{array}{l}\text { 5. Pemantauan (Monitoring) } \\
\text { Merupakan kegiatan evaluasi dengan beberapa } \\
\text { bentuk apakah yang sifatnya berkelanjutan, } \\
\text { terpisah, maupun, kombinasi keduanya yang } \\
\text { digunakan untuk memastikan apakah masing- } \\
\text { masing dari kelima komponen pengendalian } \\
\text { internal mempengaruhi fungsi-fungsi dalam } \\
\text { setiap komponen, ada dan berfungsi }\end{array}$ & $\begin{array}{l}\text { Monitoring yang dilakukan dalam melihat } \\
\text { aktivitas perusahaan baik Penjualan maupun } \\
\text { operasional menggunakan CCTV yang telah } \\
\text { terpasang di setiap ruangan kerja sehingga dapat } \\
\text { mengontrol dan melakukan pengawasan bagi } \\
\text { pegawai yang tidak melaksanakan tugasnya } \\
\text { sesuai dengan kebijakan yang ada }\end{array}$ \\
\hline
\end{tabular}

Sumber: Data hasil olahan

\subsubsection{Evaluasi Sistem Informasi Akuntansi Penjualan Tunai Pada PT. Hasjrat Abadi Cabang Malalang Manado}

Melalui hasil penelitian ini, penulis dapat menyimpulkan bahwa sistem informasi akuntansi penjualan tunai yang ada pada PT. Hasjrat Abadi Cabang Malalayang Manado sistem otorisasi dan prosedur pencatatan penerimaan kas dari penjualan tunai diotorisasi oleh bagian kasir dengan mencatat kuitansi pelunasan. Pemesanan yang dilakukan oleh pelanggan diotorisasi oleh sales dengan membuat surat pemesanan kendaraan untuk penjualan, Pencatatan akuntansi telah dikerjakan oleh bagian administrasi dan pihak yang berwenang dan telah dilaksanakan pemisahan tugas oleh masing- masing bagian, dokumen yang digunakan sudah baik karena diotorisasi oleh bagian yang tepat. Dokumen yang digunakan telah mengunakan nomor urut tercetak dan sudah didesign dengan sangat baik oleh perusahaan.

\section{Cabang Malalayang Manado dimulai konsumen harus melengkapi berkas seperti: \\ 1. KTP (yang masih beraku) suami istri atau KTP pribadi dan penjamin. \\ 2. Fotocopy bukti kepemilikan rumah atau rekening listrik (terbaru). \\ 3. Fotocopy slip gaji. \\ 4. Fotocopy surat surat keterangan penghasilan/tabungan/bukti usaha.}

4.2.3. Evaluasi Sistem Informasi Akuntasi Penjualan Kredit Pada PT. Hasjrat Abadi

Prosedur penjualan kredit pada PT.Hasjrat Abadi Cabang Malalayang Manado

\subsubsection{Evaluasi Sistem Informasi Akuntansi Penerimaan Kas Pada PT. Hasjrat Abadi Cabang Malalayang Manado}

Penerimaan Kas dari penjualan, Kas merupakan hal yang paling penting dalam setiap transaksi perusahaan. Penerapan penerimaan kas pada perusahaan PT. Hasjrat Abadi cabang malalayang manado sudah terorganisir dengan baik sistem otorisasi dan prosedur pencatatan penerimaan kas. Sistem otorisasi dan prosedur pencatatan, semua penerimaan order dari pembeli diotorisasi oleh salesman dan bertanggung jawab untuk membuat SPK. Penerimaan kas diotorisasi oleh fungsi kas untuk mencetak kuitansi lewat DMS dan ditanda tangan oleh fungsi kas dan diberi cap, dan semua pencatatan jurnal telah otomatis dalam aplikasi sistem komputer, dan telah dilakukan pemisahan tugas oleh masing- masing bagian/fungsi. 


\section{KESIMPULAN DAN SARAN}

\subsection{Kesimpulan}

Berdasarkan hasil penelitian dapat menarik kesimpulan:

1. Lingkungan Pengendalian sudah sesuai dengan teori pengendalian internal yang baik menurut COSO, dan sudah dilaksanakan secara sistematis semua proses penjualan dan penerimaan kas mendapat otorisasi dari pihak yang berwenang dengan pengendalian internal yang baik.

2. Penilaian resiko pada PT Hasjrat Abadi Cabang Malalayang Manado sudah berjalan dengan cukup baik, yaitu dengan adanya prosedur dan kebijakan mengendalikan resiko yang terjadi. Hanya saja tidak adanya batasan jumlah uang tunai yang bisa dipegang oleh bagian keuangan dan Perusahaan tidak menerapkan pengasuransian dalam perjalanan, sementara dana yang biasa masuk relatif besar.

3. Informasi dan komunikasi pada PT Hasjrat Abadi Cabang Malalayang Manado mengenai aktivitas penjualan telah diterapkan dengan cukup efektif, baik informasi yang disampaikan oleh manajemen kepada bawahannya maupun informasi yang berasal dari karyawan kepada manajemen.

4. Aktivitas Pengendalian yang dilakukan oleh PT Hasjrat Abadi Cabang Malalayang Manado sudah sesuai dengan teori $C O S O$ dimana adanya pemisahan fungsi tugas masingmasing sehingga keamanan dapat terjamin. Hal tersebut sesuai dengan teori dan terlaksanakan dengan baik pada PT. Hasjrat Abadi Cabang Malalayang Manado. Perusahaan telah menggunakan (DMS) Dealer manajemen system untuk mencatat semua transaksi. Semua data telah otomatis tersedia dalam sistem hal ini sangat efektif dan efisien bagi perusahaan.

5. Monitoring dilakukan setiap hari oleh manajemen PT. Hasjrat Abadi Cabang Malalayang Manado lewat media komunikasi dan informasi yang handal dan dapat diakses dengan cepat untuk memudahkan pengambilan keputusan.

Setelah mengetahui dan mengevaluasi sistem informasi akuntansi penjualan dan penerimaan kas PT. Hasjrat Abadi Cabang Malalayang Manado :

1. Penerapan sistem dan prosedur akuntansi penjualan dan penerimaan kas yang dijalankan perusahaan telah cukup memadai.

2. Terdapat struktur pengendalian internal yang baik (terkandung unsur lingkungan pengendalian yang baik, aktivitas pengendalian dan pengawasan yang baik).

\subsection{Saran}

1. Untuk pengamanan kas seharusnya ada pengasuransian kas yang ada ditangan dan kas yang ada diperusahaan serta kas dalam perjalanan, mengingat jumlah penerimaan kas dan pengeluaran kas relatif besar setiap hari.

2. Baik jumlah uang tunai yang dipegang, diberi batasan tertentu melalui kebijakan perusahaan untuk menghindari penyalahgunaan kas ditangan.

\section{DAFTAR PUSTAKA}

Alifa.F. Nur (2013),'Evaluasi Sistem Informasi Akuntansi Penjualan Dan Penerimaan Kas Dalam Upaya Meningkatkan Efektifitas Pengendalian Intern"Jurnal Adminsitrasi Bisnis Universitas Brawijaya.2(1) Hal-38

Any Krisnawati S.T (2013)"Analisis Sistem Informasi Akuntansi Penjualan Dan Penerimaan kas (Studi Pada Penjualan Speedy PT,Telekomunikasi Indonesia,Tbk Kandatel Malang).Jurnal Administrasi Bisnis (JAB)|Vol. 1 No. 1 April 2013| Administrasibisnis.studentjournal.ub.ac.id. Hal:62

Alvin A, Arens. Mark S, Beasley. Randal J Elder. (2010) Auditing Assurance Services 
Adri A. \&Tirtayati P.S (2015) "Evaluasi Penendalian Internal Atas Siklus Penjualan Dan Penerimaan Kas Pada PT Sinar Surya Terang"

Ariati (2015) Evaluasi Penerapan Sistem Informasi Akuntansi Penjualan Barang Dagang dan Penerimaan Dalam Upaya Meningkatkan Pengendalian Intern Pada PT.Borwita Citra Prima Kediri. Hal:5

Arlan, F. Wijaya, F, S. Alianto, H. (2012). An Analysis Of Sales Information System And Competitive Advantage (Study Case of UD. Citra Helmet). International journal of communication \& information technology.

Baramuli, judhistia P.J dan Herman Karamoy (2014). "Evaluasi Penerapan Sistem Informasi Akuntansi Penjualan pada PT.Ciputra Internasional manado”, Accountability, 3(1):113

Daoud, Hazar dan Triki Mohamed (2013"Accounting Information system in an ERP Environment and Tunisian firm performance", The International Journal of Digital Accounting Research Universitas Sfax Tunisia, 13:1-35

Dzomira. (2014). Internal controls and fraud schemes in nonprofit organizations. A guide for good practice. Research Journal of Finance and Accounting, 5 (2), 118-124.

Daud, Rochmawati dan Mindana,Valeria Mimosa.2014,Pengembangan Sistem Informasi Akuntansi Penjualan dan Penerimaan Kas Berbasis Komputer Pada Perusahaan Kecil (Studi Kasus Pada Pt.Trust Technology).Jurnal Manajemen dan Bisnis Sriwijaya Vol.12 No.1 Maret 2014

Esteria Wayan Ni. 2016. "Analisis Sistem Akuntansi Penerimaan Dan Pengeluaran Kas Pada PT. Hasjrta Abadi Manado Volume 16 No. 04 Tahun 2016"

Hamel, G (2013) Evaluasi Sistem Pengendalian Intern Terhadap Piutang pada PT.Nusantara Surya Sakti.Jurnal emba Vol.1.no.3 juni 2013.Hal 274-281 